\title{
CITIZEN PERCEPTION OF OPEN DATA AND INNOVATION IN MEXICO
}

\author{
PERCEPCIÓN CIUDADANA DEL OPEN DATA Y LA INNOVACIÓN EN MÉXICO
}

\author{
José G. Vargas-Hernandez \& Carlos Estrada Zamora* \\ University Center for Economic and Managerial Sciences \\ University of Guadalajara \\ *Corresponding author: carlosestradaz@gmail.com
}

\begin{abstract}
This paper analyses the environment of open data and its perception by Mexicans based on the National Survey on Access to Public Information and Protection of Personal Data (ENAID) 2016 and the Survey on Public Perception of Science and Technology (ENPECYT) 2015. The literature review was focused on the open data age represents a new social paradigm that has revolutionized the way that people and organizations obtain, analyze and use large amounts of information to make decisions. Mexico has mechanisms and platforms for access to open data, however, their use and contribution to real innovation is unknown. This paper focuses on this problem; the data reflect important weaknesses in the perception of the implementation of open data, along with low interest on innovation and ignorance on it.
\end{abstract}

Key words: Open data, data science, open government, innovation.

Resumen: Este trabajo analiza el entorno de los datos abiertos y su percepción por parte de los mexicanos a partir de la Encuesta Nacional de Acceso a la Información Pública y Protección de Datos Personales (ENAID) 2016 y la Encuesta sobre la Percepción Pública de la Ciencia y la Tecnología (ENPECYT) 2015. La revisión de literatura señala, que la era de los datos abiertos representa un nuevo paradigma social que ha revolucionado la forma en que las personas y las organizaciones obtienen, analizan y utilizan grandes cantidades de información para tomar decisiones, México posee mecanismos y plataformas para el acceso a datos abiertos, sin embargo, se desconoce su utilización y contribución a la innovación real. Este trabajo se enfoca en este problema, los datos reflejan importantes debilidades en la percepción de la implementación de datos abierto así como escaso interés en la innovación e ignorancia sobre la misma.

Palabras clave: Datos abiertos, ciencia de datos, gobierno abierto, innovación.

\section{Introduction}

The "data revolution" is a phenomenon triggered worldwide by the proliferation of the use of mobile devices and the internet; consists in obtaining large amounts of data on things that people and organizations perform through computer systems, storage, processing and subsequent use for decision making in different formats and applications (IEAG, 2014, Janssen, Konopnicki, Snowdon and Ojo, 2017). Technology has evolved in such a way that the capacity to obtain data is gigantic, the range of things on which there is data is enormous, and the diffusion of them through various "data products" multiplies the possibilities to know and analyze phenomena from different angles (IEAG, 2014, p.6).

In this context, the United Nations (UN) developed a work approach within its attributions, for the generation of policy frameworks that promote development for global well-being through the use of data (United Nations Global Pulse, 2016). These

\begin{tabular}{|c|c|}
\hline $\begin{array}{l}\text { EUROPEAN } \\
\text { PUBLIC SOCIAL } \\
\text { INNOVATION }\end{array}$ & $\begin{array}{c}\text { European Public \& Social Innovation Review } \\
\text { Volume 3, Issue 2, } 2018 \text { ISSN 2529-9824 } \\
\text { Creative Commons 4.0. International }\end{array}$ \\
\hline
\end{tabular}


actions reflect the relevance and great interest that people around the world are placing on the use of data. Taking into account as fundamental principles for the data revolution the "freedom of information" and "open government data" (Afful-Dadzie and Afful-Dadzie, 2017, p.665), this article reviews the good practices documented by the scientific community that works on innovation issues at the same time, also discusses the perception of Mexicans about the policy of access to public information and innovation carried out by the Mexican government.

Big Data - as it has also been called this data revolution - requires a particular technological development so that large volumes of information can be "captured, managed and processed in a reasonable time" (Pérez Marqués, 2016, p.1). To do this, software such as Hadoop has been developed, which allows communicating with physical infrastructure with a large capacity for data storage, processing, crossing and output of information from large repositories (Pérez Marqués, 2015).

Undoubtedly, when referring to open data, especially those that have content about what people do and that may be sensitive, they require standardized legal frameworks that guarantee their protection. Respect of this, Galindo (2014) points out that the open data must be arranged according to the regulation of reuse of open data, protection of personal data, delimitation of responsibility for the provision of services and the one that provides guidelines for the exercise of specific administrative services. On the other hand, innovation is a very important factor for the economic growth and profitability of organizations over time based on knowledge and specific social, economic and political factors (Espejel García, Barrera Rodríguez, Cuevas-Reyes, Ybarra Moncada and Venegas Venegas, 2017; Schumpeter, Opie and Elliott, 1983).

According to the study by Canales and Álvarez (2017), "financial restrictions" are one of the main causes for generating innovation, because organizations always work in search of new opportunities for their economic success. The innovation in the environment of the organizations pushes the strategic development of actions that allow them, the creation of value in "the areas or services that present the most deficiency", from an adequate integration with its context (and the investment in research and technological development -imprescindibles-), that allows them "a substantial advance that corresponds with the system's demands", and that this, gives its target market "more reliability and credibility" (Hernández, Cardona and Del Rio, 2017).

Making a conjunction of the terms addressed in this introduction, Open Data allows innovation from different ways, that is, from a more integral approach, because the transformations in governments to make large amounts of data available to people, not they only represent a novelty for the public administrations in front of the citizenship, if not that, it produces more innovation by allowing access to the open data to individuals (citizens and organizations), so that these, in turn, produce new proposals that help solve problems (Janssen et al., 2017; Reggi and Dawes, 2016).

Governments must change, reorganize their structures and include in their operational policies the models of action that allow an adoption according to the new paradigm that open data is imposing, Janssen et al. (2017) compiles from six investigations in the matter, that these transformations must be carried out around the "policies and strategies", at the "organizational" level, in the "governance of the data" and in the deployment of infrastructure and at the technical level, for the consummation of this aforementioned data revolution.

For this work, the data collection effort made by the Mexican government through its National Institute of Statistics and Geography (INEGI) in its National Survey on Access to Public Information and Protection of Personal Data (ENAID) was taken as a framework for analysis, 2016 and the Survey on the Public Perception of Science and Technology (ENPECYT) 2015. Collectively, they reflect the public perception of, access to public information provided by the government, and the science and technology activity that generates innovation in the country. Both works allow analyzing and establishing a frame of reference about what Mexicans assume is done in the matter by public institutions. 


\section{Background}

Governments, as main social leaders, have played a transcendental role in the development of this data revolution, through government Open Data policies for transparency and access to public information, of which, various initiatives have been consolidated to generate quality data for citizens and institutions (public and private). The government to take initiative in this regard was the United States, during the administration of President Barack Obama (Okamoto, 2017) in January 2009.

Initiatives on open public data platforms had their beginnings and are mostly applied in developed nations such as Germany, the United Kingdom and Canada. However, in countries such as "Kenya, Morocco, Tunisia, South Africa, Uganda and Cameroon", they have started already to work on Open Data initiatives that contribute to generating opportunities for innovation in these developing countries (Amugongo, Nggada and Sieck, 2016).

Mexico, according to the Open Data Barometer of the (World Wide Web Foundation, 2018), is in the 11th position worldwide in the development of its open data policy according to the measurement of the year 2016. This, due to the policies, laws, regulations and guidelines on digital inclusion and, transparency and accountability, which since 2013 the Mexican government has promoted and shared with other multilateral agreements such as the "Digital Agenda of the Pacific Alliance" (Pacific Alliance, 2017 General Congress of the United Mexican States, 2015, Presidency of the Republic, 2013, 2015b, 2015a).

Innovation in open data policies has had significant obstacles to its implementation in government administrations, according to Chatfield and Reddick (2018) these obstacles come from sources of resistance "political, bureaucratic, and institutional", due to the implications in terms of surrender of accounts, personnel and allocation of resources to carry it out. For this reason, the aforementioned authors found in their study the importance of disseminating the advantages of innovating in Open Data Government for society, starting with "the first adopters" until achieving generalized (or mostly generalized) awareness of their advantage.
In terms of innovation, since the Second World War, governments around the world have promoted policies with a "structuralism" approach that has integrated various sectors of society and international organizations for their conformation. These policies have focused on specific to the interests of nations (Loray, 2017).

\section{Theoretical-conceptual review}

Several countries around the world have developed online platforms to have open data that can be used by citizens, institutions and the business sector, to add value to their functions through innovations that are contributing to the resolution of their daily problems.

The work of Munigala, Oinonen and Ekman (2018) analyzes the success of the Finnish educational system from a case on the perspective of the design of innovative environments that allow people to be agents of change (the students in that case), this, through the generation of scenarios that enable the resolution of problems from a holistic, personalized, flexible and collaborative perspective.

Namibia works to develop an open data portal based on good practices from leading portals worldwide. Amugongo et al. (2016) conducted a content analysis of the Open Data portals of the United States, the United Kingdom and Kenya, of which they identified the opportunities to improve the portal scheme (in beta version then) of Namibia and, from this, they project that it becomes an "essential driver of innovation" by shortening the gap "between data and citizens". Also the work of Seegolam, Sukhoo and Bhoyroo (2016), talks about the benefits that for Kenya has brought the implementation of government open data portals and the great opportunities they can offer for nations with a low level of development and high marginalization.

According to Blal, Singal and Templin (2018, p.86) the innovation of a business model redefines an existing product / service and the way in which it is provided to the client, which opens up new possibilities in the market existing to catch a certain audience. They developed a model in which they determined that "the performance of sales" of the service of intermediation for accommodation on the 
Internet Airbnb is given by: the location of the accommodation, the concept of accommodation offered, the guest segment to which it is addressed, the price, the offer of accommodation options, the recommendation of other users about the place that is offered and the season of the year.

Zopiatis and Theocharous (2018) analyzed another case where innovation in the hospitality sector was benefited thanks to the implementation of innovative human resources strategies with the hotel staff of Cyprus, which was affected by the Greek economic crisis in 2013, after the bankruptcy of its banking institutions. By improving the organizational culture based on the results of a study, the staff improved their commitment to the organization thanks to the opportunities provided to them to contribute in a participatory way in the improvement of the same.

The open innovation that drove Open Data policies in the Brazilian government through the participation of citizens in its conformation, according to Freitas and Dacorso (2014), represented a great challenge for that government, due to the resistance and apathy of the community to collaborate with the government in the creation of public policies through the platforms developed for it, however, laid the foundations for the development of new schemes that allow this to occur in the future.

New forms of social and private participation have arisen towards the reuse of data such as hackatoons, living labs and data collaborators, which correspond to initiatives that push governments to transformations for the data era, where its commitment to generate innovation from these initiatives pushes the public organization to pay attention to the "governance of data" and the establishment of incentives to achieve it (Janssen et al., 2017). Reggi and Dawes (2016) developed, from a case study in Bologna, Italy, an innovation ecosystem model using Open Data Government, based on the study of the framework that leads to the publication of open data and the interdependence of its elements, in which they found the importance of political benefits, the creation of policies and the participation of society, to generate applications for the benefit of the population.
Another interesting approach focused on innovation in scientific research is that posed by Rusyaeva and Saltykov (2017), in which they establish a series of life cycle stages of research innovations for science, which they classify based on their contribution to new knowledge (ranging from the least solid approaches to the most consolidated knowledge by the scientific community). This approach is an interesting and highly useful framework in determining what really innovates and what lacks profitability as an innovative idea.

\section{Research method}

This article takes as a matter of analysis two data collection works carried out by INEGI (Mexico) together with other institutions such as the National Council of Science and Technology (CONACYT) and the National Institute of Transparency, Access to Information and Data Protection Personal (INAI): the National Survey on Access to Public Information and Protection of Personal Data (ENAID) 2016 and the Survey on Public Perception of Science and Technology (ENPECYT) 2015, the first conducted between January and April of the year 2016 and the second during the year 2015 .

The National Survey of Access to Public Information and Protection of Personal Data (ENAID) 2016 according to the National Institute of Statistics and Geography of Mexico and the National Institute of Transparency, Access to Information and Protection of Personal Data of Mexico (2016, sp ), aims to obtain statistical information that allows to measure the degree of knowledge, perceptions and attitudes that influence the exercise of rights of access to information and protection of personal data.

The work mentioned in the previous paragraph was applied to people over 18 years of age in 14,400 homes (urban areas over one hundred thousand inhabitants) nationwide (Mexico), with a confidence level of $90 \%$, and a margin of error of $8 \%$, using a probabilistic sampling "multi-stage, stratified and by conglomerates".

For its part, in the design of the Survey on the Public Perception of Science and Technology (ENPECYT) 2015, it was established as an objective "to gather relevant 
information for the generation of indicators that measure the knowledge, understanding and attitude of people, related to scientific and technological activities "(National Institute of Statistics and Geography of Mexico and National Council of Science and Technology of Mexico, 2015). In this particular work, given that the objective is very broad for our work, we take into account the results related to sections "B" ("Information sources of science and technology") and "E" ("Perception of the social role of science and technology, basic research, scientists and government ") of said survey.

The survey referred to in the previous paragraph, was raised between September 14 and October 13, 2015 among people over 18 years in 3,159 homes (located in urban areas of more than one hundred thousand inhabitants) a level of confidence of $90 \%$, and a margin of error of $15 \%$, made by stratified sampling, "by conglomerates and two-stage which will allow inferences to be made for the addition of the units under study". From the data obtained from open access in database format (.dbf) from the section of "microdata", of each of the sections of the aforementioned surveys, on the INEGI website (National Institute of Statistics and Geography (Mexico), 2018), the following actions will be carried out for each:

Of the survey on Public Perception of Science and Technology (ENPECYT) 2015, only the basic review of the descriptive statistics (frequency tables) of the variables of interest of this work was carried out.

Based on the data base of the National Survey of Access to Public Information and Protection of Personal Data (ENAID) 2016, a multiple linear regression analysis was carried out in addition to the frequency tables with the results, to identify the statistical significance of the variables regarding the use of government data by Mexicans, we were particularly interested in this study the sections on: "Perception and knowledge on the right of access to information", "Consultation on procedures and services" and "Obligations of transparency".

Finally, the results analysis was carried out that include the results on the variables studied, accompanied by the corresponding interpretations regarding the study theme of this work. Conclusions are made with the learning and results of this work, the contributions to knowledge and recommendations for future studies in the field.

\section{Analysis of results}

As it was approached in the methodological approach of this work, the items that were considered relevant for the study of the innovation that the Survey on the Public Perception of Science and Technology (ENPECYT) 2015 collected from the percentages of the frequencies of the answers of the database of said survey.

Subsequently, a linear regression analysis is made from the dependent variable in the questionnaire: people who stated that they would prefer to use "internet" to obtain government information. On the independent variables: those corresponding to the questions were introduced: "If you would like to know government information, what means do you identify to obtain it?", "In 2015, for daily life, for work reasons or to be informed, what type of information does the government generate? "and" in general, do you believe that obtaining information generated by the government is ...?

\section{a. Innovation}

The first interesting data is the percentage of affirmative answers regarding the interest in being a researcher $(4.8 \%)$, academic researcher $(4.4 \%)$ or inventor $(3.3 \%)$, that is, very few declared interest in engaging in activities that can be considered much linked to innovation. When the participants were questioned about the dimension of their interest in new inventions, scientific discoveries and technological development", they answered: Very large $(9.6 \%)$, large $(28.4 \%)$, moderate $(37.5 \%)$ and Null $(24.5 \%)$, evidencing an intermediate interest in these issues by the participating population, in addition, the survey, with the objective of measuring the reasons for this last questioning, showed that these are not of particular interest to the participants these subjects $(8.4 \%)$ or do not have time $(5 \%)$, ignores them $(5.6 \%)$ or does not understand them $(5.3 \%)$.

Likewise, another part of the study focused on the means of accessing information on "scientific developments" (item more closely related to innovation), to which the participants 
responded that they give more importance to inform themselves about them, to the Internet $(36.5 \%)$ and television (16.9\%). It is important to note that, $62.5 \%$ of the participants said that they access the Internet.

Another of the questions in the study, touched on the level of confidence perceived by citizens regarding the knowledge domain of the government against science and technology issues, to which the participants responded that it is: "very reliable" (1.2 \%), "Reliable" (15.2\%), "unreliable" (41.4\%) and "not at all reliable" (40.4\%), leaving very clear their perception of distrust in the subject when the government provides such information.

Participants were also questioned about their perception of the "understanding" of the concepts: innovation (highlighting the answers "regular" with $43.1 \%$ and "bad" with $22.9 \%$ ) and invention (repeating "regular" with $43.1 \%$ of the answers and "bad" with 26.5\%). The conjectures are left to the results shown. In the same way, the participants were asked about science and technological development, particularly in terms of whether the role of scientific research for technological development is fundamental, affirmation, for which $-65.1 \%$ of the participants- answered "in agreement".

As for whether the internet "is essential for the development of new economic activities", $59.2 \%$ of the participants said they "agree" with this statement. While, with the affirmation of whether the Internet "will help improve the quality of life of people," $43 \%$ of respondents answered "in agreement" and $36.8 \%$ said they "disagree". It should be noted that, in the three previous questionnaires, the response rate of the "strongly agree" option exceeded $10 \%$ of the responses, so there is a strong tendency to support these statements by the respondents, except in the case of the last one.

On the other hand, in the section of the study that includes the affirmation about whether "the government should invest more in scientific research", the participants showed their support mostly $(87.7 \%)$ in favor. Affirmation supported by the questioning about the perception of the amount invested by the government in "support for scientific research", in which, $68.7 \%$ responded that they believe it is "very little".
Finally, within the topics that are of interest for this work, it is observed the results that questioned about the perception of importance of the participants about the institution that "makes the most important developments in science, technology and innovation", where only $0.9 \%$ of the participants considered the "government" as a fundamental part for this kind of development and, $8.8 \%$ of the participants, considered that those who contribute most to this area, are the "research centers".

\section{b. Access to public information (Open Data)}

In this section, the multivariate statistical analysis is performed with the variables indicated in the introduction of this section with the data of the National Survey of Access to Public Information and Protection of Personal Data (ENAID) 2016, as well as the analysis of the statistics of frequency that some variables of said survey provide and that are of interest in this work.

The multiple regression analysis, according to Mejía Trejo (2017, p.191), is a "more versatile and widely used dependence technique, applicable in any field of administration sciences", consisting of the definition of a variable dependent and a group of independent variables and determine the power of the occurrence of the dependent variable for each occurrence of each of the independent variables.

The answer option "internet" of the question "How would you like to hear about the information generated by the government?" was used as a dependent variable, due to the interest of this work to approach the nearest perspective of the stock data of said survey on the use of Open Data. As independent variables, 24 answers were used corresponding to the questions posed in the second introductory paragraph of this section.

Although the generated model did not obtain values consistent with their coefficients of determination $\mathrm{r} 2$ (greater than -generally accepted in economic-administrative studies$60 \%$ ), mainly due to the deficiencies in the disposition of the values in the base of data (and that the validation of the statistical consistency of the base of "Microdata" provided by INEGI 
is outside the reach of the objective of this work), in addition, the variables used can measure different elements at a qualitative level and, it is also taken consideration of the high sensitivity of the model due to the fact that it worked with a very large sample. However, the following were found as statistically significant values for the dependent variable:

Search for information on the government website; search in transparency portals; they look for information about legislation; they look for laws of right of access to information; look for requirements or procedures of government services; they are concerned about the ease or difficulty of accessing government information; they are not interested in information about the government; information on social programs; seek information about political parties and elections; they look for newspapers or official publications; do not know what government information to use; seek information about public hospitals; government employment exchange; they look for the governmental organization chart; they look for information about combating poverty; they look for data on emergency services; prefer the information of the transparency offices and; they consult information about drinking water services.

As an interpretation of the theoretical value of the aforementioned variables, it is assumed in the order in which they were mentioned, their greatest power to affect the model when people prefer to use the Internet to learn government information.

Interestingly, $38.3 \%$ said that they consult government websites to get information, $14.7 \%$ prefer to go directly to a government office to request information, and $10.5 \%$ said they visit government sites to consult official journals. In addition, $40.5 \%$ of the interviewees said that it is difficult to obtain information generated by the government and $36.6 \%$ said that it is easy for them to carry out said action.

Regarding the information that people search on the internet about the government, $27.6 \%$ highlight public hospitals, $26.4 \%$ health campaigns, $27.7 \%$ on public schools, $24 \%$ potable water service, and the highest percentage is $43.6 \%$ of requirements for procedures or services. About the means, by which they prefer to obtain information from the government, stand out the television with a $57.3 \%$ and with $38.2 \%$ the Internet. $96.9 \%$ of respondents say that government information should be available to all. On the other hand, $50.4 \%$ of the participants in the study said they do not know about the existence of the law that guarantees access to public information, while $48.7 \%$ said yes.

In the case of services based on open data, the participants in the study were consulted on various topics, for example: consultation on the location of places (the highest percentage responded was $34.9 \%$ that does it through the internet), climate (highlighting: $39.8 \%$ do it through television and $23.1 \%$ use internet), about procedures and public services (18.9\% use internet and $11.7 \%$ go directly to a government office), public transport (8.6\% on the internet, $8.2 \%$ directly with the provider of the service and by friends or relatives $5.3 \%$, as the most noteworthy), and health information (21.9\% directly in the institution and $14.5 \%$ online, mainly).

Regarding the economic situation of the country (20.9\% through television and also highlighting $12.2 \%$ through internet), on issues related to public education (18.7\% through Internet, $11.5 \%$ directly at school or office and $10.7 \%$ through television), about natural disasters $(37.2 \%$ through television and $16.6 \%$ through Internet as outstanding values), about traffic (12.9\% through television, $8.9 \%$ through radio and $11 \%$ over internet), government releases $(18.8 \%$ over the television and $9.6 \%$ by internet as maximum declared percentages), social programs $(14.1 \%$ through television and $10.5 \%$ via internet in a significant way), political parties $(16.3 \%$ through television and 8.1 over the internet).

In terms of confidence in the information provided by the government, the topics with the highest weightings were: $50.9 \%$ natural disasters, $37.6 \%$ public health services, $35.7 \%$ public education. The subjects in which they distrust most manifested were: $48.8 \%$ elections, $36.4 \%$ on the performance of the governments, $36.4 \%$ the state of the economy, $34.4 \%$ on the salary and salary of public officials, $33.8 \%$ on the use of money public and $29.7 \%$ in the reduction of poverty.

They also reviewed the type of information queries that people declared they made online on government websites, of which it stands out: only $7.9 \%$ said they consulted information about the structure, $6.2 \%$ consulted about the 
directory, salaries and civil servant profile, $5.9 \%$ reviewed citizen participation programs and 12,306 people declared that they made other types of consultations not contained in the form. On those consultations, only $11.9 \%$ said that "yes" found what they were looking for, $11.7 \%$ said it was free, $11.3 \%$ said they found this information useful, $11.2 \%$ said it was available online, $10.8 \%$ said that if it could be visualized in multiple devices, $10.1 \%$ said that it was easily accessible and $9.8 \%$ said that if it was complete and it solved its doubt, mainly.

Finally, regarding the accessibility and management of the government pages, $10 \%$ said that they are, and said that $7.4 \%$ of users said they were "somewhat satisfied", mainly.

\section{Conclusions}

The innovation, coming mainly from the scientific and technological development, according to the data that the ENPECYT showed, shows the low interest and knowledge on the development of innovations that the Mexicans manifest. Who, despite having access to technological tools, such as the Internet, said they do not have enough support and solidity from government institutions to generate sustained development of such a fundamental activity: innovate.

The main and richest analysis of this work was focused on the data that the ENAID 2016 showed, from which interesting relationships emerged from the way in which people consult information generated by the government, based on their taste for accessing data of this type through the Internet. Thus, it can be considered that most of the information consulted by Mexicans about the government is related to the functioning of the government, such as services, procedures or activities related to government work.

Although a high percentage of users said that they access information about the government through the Internet, public institutions and the platforms they have set up to do so, they are not at all friendly (accessible) to dispose of said data. The tables of frequencies that this latest survey shows a high dependence on television (still) as the main information medium, as well as the high preference to look for information directly in the windows of the government or the institutions of those who need it.

Regarding the information provided in online platforms based on government efforts in Open Data, such as access to maps or the climate, percentages of moderate consultation are maintained, as well as for e-government (online government services). However, the level of distrust in the information provided in the government portals is enormous, especially in information on issues that may be related to acts of corruption or misuse of public resources.

At the moment, with the data available, Open Data for innovation in Mexico is far from being a causal relationship fully consolidated as in other countries, although there are efforts to open the information through open data portals, the layout, the formats and their configuration for easy use, are far from being effective, as long as people are not trained or develop applications to understand more easily the data that are available there. While not having a population group with better technological capabilities, the use of open data will remain limited, taken advantage of by a few, and for this it is necessary to provide knowledge to the population for the understanding of innovation as a fundamental activity for the survival of their organizations through effective decisionmaking (better informed and competitive).

It should be noted that the data presented here does not directly measure the relationships of Open Data for innovation, but rather that it uses information resources that allows approaching the problem through indicators that can be used as a reference to weigh scenarios for both variables.

This work aims to contribute to the generation of awareness by governments, to promote policies to better measure the data revolution, to evaluate their work as providers of vital information for decision making of individuals and organizations and, not only to be providers of transparency information and governmental procedures, but also valuable repository givers to contribute to the development of the nation.

In the future, it is propose the evaluation of Mexican Open Data portals, to contrast their configuration and demand, with those of other countries that generate good practices in the matter. Likewise, the bibliometric or documentary research of the success cases of 
open data applications in the country, in order to contribute to the formation of a more consistent analytical framework, analyze and better understand this revolution of open data in an empirical way.

\section{References}

Afful-Dadzie, E., \& Afful-Dadzie, A. (2017). Liberation of public data: Exploring central themes in open government data and freedom of information research. International Journal of Information Management, 37(6), 664-672. https://doi.org/10.1016/j.ijinfomgt.2017.05.009

Alianza del Pacífico. (2017, junio 30). Declaración de Cali, La Agenda Digital de la Alianza del Pacífico. Recuperado a partir de https://alianzapacifico.net/wp-content/uploads/2017/06/DECLARACIÓNDE-CALI-V111.pdf

Amugongo, L. M., Nggada, S. H., \& Sieck, J. (2016). Open Data Portal - A Technical Enabler to Drive Innovation in Namibia (pp. 80-86). IEEE. https://doi.org/10.1109/OBD.2016.19

Blal, I., Singal, M., \& Templin, J. (2018). Airbnb's effect on hotel sales growth. International Journal of Hospitality Management, 73, 85-92. https://doi.org/10.1016/j.ijhm.2018.02.006

Canales, M., \& Álvarez, R. (2017). Impacto de los obstáculos al conocimiento en la innovación de las empresas chilenas. Journal of Technology Management \& Innovation, 12(3), 78-85. https://doi.org/10.4067/S0718-27242017000300008

Chatfield, A. T., \& Reddick, C. G. (2018). The role of policy entrepreneurs in open government data policy innovation diffusion: An analysis of Australian Federal and State Governments. Government Information Quarterly, 35(1), 123-134. https://doi.org/10.1016/j.giq.2017.10.004

Congreso General de los Estados Unidos Mexicanos (2015). Ley General de Transparencia y Acceso a la Información Pública. $\quad$ Recuperado a p artir $\quad$ de http://www.dof.gob.mx/nota_detalle.php?codigo=5391143\&fecha=04/05/2015

Espejel García, A., Barrera Rodríguez, A. I., Cuevas-Reyes, V., Ybarra Moncada, M. C., \& Venegas Venegas, J. A. (2017). Sistemas de innovación y patrones de interacción local en el sector rural en México. Nova Scientia, 9(19). https://doi.org/10.21640/ns.v9i19.827

Freitas, R. K. V. de, \& Dacorso, A. L. R. (2014). Inovação aberta na gestão pública: análise do plano de ação brasileiro para a Open Government Partnership. Revista de Administração Pública, 48(4), 869-888. https://doi.org/10.1590/0034-76121545

Galindo, F. (2014). La regulación de los datos abiertos. Ibersid. 8, 13-18.

Hernández, H. G., Cardona, D. A., \& Del Rio, J. L. (2017). Direccionamiento Estratégico: Proyección de la Innovación Tecnológica y Gestión Administrativa en las Pequeñas Empresas. Información Tecnológica, 28(5), 15-22. https://doi.org/10.4067/S0718-07642017000500003

IEAG, U. N. S.-G. I. E. A. (2014). A World That Counts: Mobilising The Data Revolution for Sustainable Development. (p. 6). New York. Recuperado a partir de http://www.undatarevolution.org/wpcontent/uploads/2014/11/A-World-That-Counts.pdf

Instituto Nacional de Estadística y Geografía de México, I., \& Consejo Nacional de Ciencia y Tecnología de México, C. (2015). Encuesta Nacional sobre la Percepción Pública de la Ciencia y la Tecnología en México 2015 (ENPECYT) Síntesis metodológica.

Instituto Nacional de Estadística y Geografía de México, I., \& Instituto Nacional de Transparencia, Acceso a la Información y Protección de Datos Personales de México, I. (2016). Encuesta Nacional de Acceso a la Información Pública y Protección de Datos Personales 2016 Marco conceptual. Recuperado a partir

de http://internet.contenidos.inegi.org.mx/contenidos/Productos/prod_serv/contenidos/espanol/bvinegi/p roductos/nueva_estruc/702825089405.pdf

Instituto Nacional de Estadística y Geografía (México), I. (2018). Microdatos. Recuperado el 1 de mayo de 2018, a partir de http://www.inegi.org.mx/est/contenidos/proyectos/accesomicrodatos/

Janssen, M., Konopnicki, D., Snowdon, J. L., \& Ojo, A. (2017). Driving public sector innovation using big and open linked data (BOLD). Information Systems Frontiers, 19(2), 189-195. https://doi.org/10.1007/s10796-017-9746-2

Loray, R. (2017). Políticas públicas en ciencia, tecnología e innovación: tendencias regionales y espacios de convergencia. Revista de Estudios Sociales No.35, 62, 68-80. https://doi.org/10.7440/res62.2017.07 
Mejía Trejo, J. (2017). Las Ciencias de la Administración y el Análisis Multivariante. Proyectos de Investigación, análisis y discusión de resultados. Tomo I. Las Técnicas Dependientes. México: Universidad de Guadalajara.

Munigala, V., Oinonen, P., \& Ekman, K. (2018). Envisioning future innovative experimental ecosystems through the foresight approach. Case: Design Factory. European Journal of Futures Research, 6(1). https://doi.org/10.1007/s40309-017-0128-2

Okamoto, K. (2017). Introducing Open Government Data. The Reference Librarian, 58(2), 111-123. https://doi.org/10.1080/02763877.2016.1199005

Pérez Marqués, M. (2015). Big Data: Técnicas, herramientas y aplicaciones. Madrid: RC Libros.

Pérez Marqués, M. (2016). Big data: técnicas, herramientas y aplicaciones.

Presidencia de la República. Plan Nacional de Desarrollo (2013). Recuperado a partir de https:/www.google.com/url?sa=t\&rct=j\&q=\&esrc=s\&source=web\&cd=3\&cad=rja \&uact=8\&ved=0 ahUKEwj0mtGk1MraAhVPiqwKHaH6BmEQFghDMAI\&url=http\%3A\%2F\%2Fwww.dof.gob.mx \%2Fnota_detalle.php\%3Fcodigo\%3D5299464\%26fecha\%3D20\%2F05\%2F2013\&usg=AOvVaw2Q qzbiFGSCMYwQA_79ZikG

Presidencia de la República, M. Guía de Implementación de la Política de Datos Abiertos (2015a). Recuperado

a partir http://www.dof.gob.mx/nota_detalle.php?codigo=5397117\&fecha=18/06/2015

Presidencia de la República, M. Regulación en Materia de Datos Abiertos (2015b). Recuperado a partir de http://www.dof.gob.mx/nota_detalle.php?codigo=5382838\&fecha=20/02/2015

Reggi, L., \& Dawes, S. (2016). Open Government Data Ecosystems: Linking Transparency for Innovation with Transparency for Participation and Accountability. En H. J. Scholl, O. Glassey, M. Janssen, B. Klievink, I. Lindgren, P. Parycek, ... D. Sá Soares (Eds.), Electronic Government (Vol. 9820, pp. 74-86). Cham: Springer International Publishing. https://doi.org/10.1007/978-3-319-44421-5_6

Rusyaeva, E. Y., \& Saltykov, S. A. (2017). Identification of the stage in the life cycle of innovation: Matrix, technique and open data (pp. 1-3). IEEE. https://doi.org/10.1109/MLSD.2017.8109680

Schumpeter, J. A., Opie, R., \& Elliott, J. E. (1983). The theory of economic development: an inquiry into profits, capital, credit, interest, and the business cycle. Recuperado a partir de http://search.ebscohost.com/login.aspx?direct=true \&scope=site \&db=nlebk\&db=nlabk\&AN=683710

Seegolam, A., Sukhoo, A., \& Bhoyroo, V. (2016). Spurring innovation through Open Government Data for Africa (pp. 1-12). IEEE. https://doi.org/10.1109/ISTAFRICA.2016.7530638

United Nations Global Pulse. (2016). Global Pulse Annual Report 2016. New York: United Nations. Recuperado

a partir

de http://unglobalpulse.org/sites/default/files/UNGP\%20Report\%202016_DIGITAL\%20VERSION.pdf

World Wide Web Foundation. (2018). Open Data Barometer. Recuperado el 17 de abril de 2018, a partir de https://opendatabarometer.org

Zopiatis, A., \& Theocharous, A. L. (2018). PRAXIS : The determining element of innovation behavior in the hospitality industry. Journal of Hospitality and Tourism Management, 35, 9-16. https://doi.org/10.1016/j.jhtm.2017.12.004 